\title{
EFFECTS OF MULCHES ON NURSERY SEEDBEDS OF WHITE SPRUCE ${ }^{1}$
}

\author{
By R. E. MULLIN ${ }^{2}$
}

\begin{abstract}
Several kinds of seedbed mulch were used in an experiment to study frost heaving of white spruce (PICEA GLAUCA (Moench) Voss) in a nursery. Treatments consisted of silica gravel (of three sizes), hardwood sawdust, vermiculite, shredded sphagnum, mixed silica and sphagnum, and rye straw (the regular nursery mulch). These were applied to beds sown in the fall of 1958, 1959 and 1960. Shading of beds during the winter between the first and second growing seasons was also examined.

During the first growing season, several counts were made of the number of trees and weeds. At the beginning of the second growing season a count was made of the trees heaved and the residual stand. At the beginning of the third growing season, samples were taken for laboratory measurements of top length. root length, stem diameter, oven-dry weight and top-root ratio.

The sawdust mulch was superior in most respects. It permitted the highest germination and survival, better prevention of heaving than rye straw, and better weed control than rye straw. Although the sawdust mulch treatment produced small and poorly balanced trees this was believed due chiefly to high bed density, and compared favourably with the rye straw. The use of hardwood sawdust as a mulch offered considerable advantage over the presently used rye-straw.

Heaving was found to be a minor cause of mortality over the three year period examined. Shading of the beds offered no advantage in reducing this loss.

\section{INTRODUCTION}

In some years there have been severe losses from frost heaving in nurseries of the Ontario Department of Lands and Forests. The Iosses have varied substantially by nursery, by tree species, and by year. They have often appeared most severe in the 1-0 seedbeds of white spruce (Picea glauca (Moench) Voss) at the Kemptville Nursery, about 30 miles south of Ottawa.

It was considered that a change in mulching practice might help to reduce these losses. In the standard procedure the seedbeds are prepared and sown in late fall, and covered with a two- to four-inch layer of rye straw for the winter. This mulch is removed in the spring, after signs of seed emergence, and the seedbeds are left unprotected for the following winter. In comparison with this procedure it was decided to examine several types of mulch which could be permanently left on the seedbeds, eliminating the expense of removal, and perhaps providing some protection against frost heaving.
\end{abstract}

\footnotetext{
${ }^{1}$ Contribution No. 65-18. Ontario Department of Lands and Forests, Research Branch, Maple, Ontario, Canada.

${ }^{2}$ Research Forester.
} 


\section{REVIEW OF LITERATURE}

The purposes of mulching may vary considerably. Generally, in Ontario, these are three: to protect the beds and seeds from sun, wind and rain damage until germination in the spring; to keep the bed surface moist; and to keep the beds cold in the spring so that germination will be delayed until after the danger of late spring frosts. Stoeckeler and Jones(19) have found this delay to be about 10-14 days in the Lake States. Krussman(12) noted that mulches may also be used to reduce frost penetration of the soil, to keep the soil porous and crumbly, and to suppress weeds. A further purpose may be to prevent frost heaving $(18,23)$.

A great many materials for mulching have been suggested. Toumey and Korstian (21) listed the following: hardwood or pine leaves, bracken fern hay or straw, scrim (coarse cotton), cheesecloth and burlap. Other materials or combinations mentioned are: $1 / 4$-inch sawdust with polyethylene film on top ${ }^{(7)}$, peat, grass, litter, chips from a mechanical chipper composted with earth ${ }^{(12)}$, compost, ground peat (and their mixture), rotted needle litter or tanbark (for soil with $\mathrm{pH}$ ), cone scales, moss ${ }^{(18)}$; grit (or fine gravel) ${ }^{(2)}$, paper pulp, aluminum foil, corncobs, asphalt, etc. ${ }^{(8)}$.

The bulk of the literature however, has dealt with the use of sawdust as a mulch. Clifford $(5)$ compared sawdust with straw for mulching red, white, and jack pine (Pinus resinosa Ait.; $P$. strobus L.; $P$. banksiana Lamb.) and found that with sawdust he obtained a better germination and a better final stand. Knight(10) found that sawdust seed cover $1 / 2$-inch deep was better than sand in obtaining germination.

Many warnings and comments on the dangers of the use of sawdust as a mulch have been issued. Stoeckeler and Jones(19) stated that sawdust "cannot safely be left on the bed during the period of germination and early seedling development", but no data or reasons for the statement were given. Sawdust mulch has been found to affect soil temperature. At a depth of four inches the soil temperature was lower under a two inch layer of sawdust than at the same depth under bare soil, particularly in July; although late in the fall the soil under the mulch was warmer than the bare soil ${ }^{(22)}$. Another study showed that a surface temperature of $138^{\circ} \mathrm{F}$. was reached on seedbeds mulched with sawdust, but only $125^{\circ} \mathrm{F}$. on exposed soil(14).

There has also been a suggestion that sawdust may introduce toxic substances or diseases. Bollen and $\mathrm{Lu}^{(4)}$ found no toxicity from sawdust. Allison and Anderson(1) found that any toxicity disappeared within a few weeks. Bloomberg(3) reported cases of fungus diseases possibly, introduced to the nursery by the use of residues such as sawdust, straw, or hay. He concluded that fresh sawdust from sound conifers seemed to be safest.

The effect of sawdust mulch on soil $\mathrm{pH}$ has also been considered. The influence however is very small, in some cases no measurable effect being found ${ }^{(0)}$ and in others only a minor effect ${ }^{(1,4)}$.

The chief disadvantage of sawdust observed has been the effect on nutrition. Rupf et al(1S) noted the general deficiency of sawdust as a fertilizer Several authors have noted that sawdust depletes the available soil nitrogen, both ammonia and nitrates $(1,4,9,13)$, although it increases total nitrogen 
content(9). However, the nitrogen depletion can be avoided by applications of nitrogen fertilizers $(1,4,11,17)$.

Wycoff ${ }^{(23)}$ has reported the successful use of sawdust as a mulch for a period of over 11 years, to prevent frost heaving, and to improve the soil.

\section{Methods and Materials}

In the fall of 1958, an experimental design was superimposed on a section of white spruce seedbeds at the Kemptville Nursery. The beds had been formed, sown, and the seeds covered with sand, in the usual manner. This design consisted of five replications of 18 fully randomized plots (ten feet by three and a half feet). Each plot was subjected to one of the following treatments.

Treatment

Number Treatment Type

1. Silica gravel, $\# 4$ mesh (coarse), $1 / 2 "$ depth.

2. Silica gravel, $\# 6$ mesh (medium), 1/2" depth.

3. Silica gravel, $\# 8$ mesh (fine), $1 / 2$ " depth.

4. Sawdust, hardwood, $1 / 2$ " depth.

5. Vermiculite, $1 / 2$ " depth.

6. Sphagnum, shredded, $1 / 2$ " depth.

7. Sphagnum and Silica, $1 / 4$ " finely shredded sphagnum, with $1 / 4$ " silica gravel ( $\# 6$ mesh) on top.

8. Fibre mat, $1 / 4$ " roll of wood fibre mat.

9. Rye straw (control), about $3^{\prime \prime}$ depth, which was removed in the spring.

In addition, there was a shaded phase (S) of each treatment, in which the lath seedbed shade which is used for the first and part of the second growing season was left on the beds for the overwintering 1-0 stage; and non-shaded phase $(\mathrm{N})$ in which the shade was to be removed for the winter.

In the spring of 1959, three one-foot wide sampling strips were marked across each ten-foot plot ( 3.5 feet wide). Counts were taken within these strips at several times during the year, of the number of trees and weeds. After each count the weeds were pulled by hand. Following the winter of 1959-60, at the 1-0 stage, a count was made of the number of trees remaining, and of the number of trees heaved. In the spring of 1961, random samples of the then 2-0 stock were taken for measurement in the laboratory.

The foregoing was Part A of the experiment. The test was repeated on seedbeds established in the fall of 1959, Part B, and in the fall of 1960 , Part $\mathrm{C}$, excluding both phases of treatment No. 8. This treatment was discontinued because of unsatisfactory results in the first year, as the fibre mat did not break up sufficiently to permit the seedlings to emerge.

\section{REsults AND Discussion}

From the data obtained, several aspects of the effects of the mulches and shading can be examined. 


\section{Effect of Mulches on Germination and Survival}

In each part of the experiment, three or four counts were made during the first growing season; tallying living and dead trees separately. The total is not an accurate measurement of germination of course, as in some treatments the seed may have germinated but not emerged.

In Figure 1, are shown the highest total number of trees, living plus dead, recorded for each treatment. The data are given in terms of average density per square foot. At this stage the winter shading had not been applied.

One feature is apparent: namely, that treatment No. 4, the sawdust mulch, had inhibited germination and emergence least. The differences are statistically significant at the 0.1 per cent level in all years. Clifford ${ }^{(5)}$ also obtained better germination with sawdust than with straw, although he was working with red, white and jack pine rather than white spruce.

The nurseryman is also interested, however, in the effects of the treatments on subsequent mortality, and hence on the final stand. In Table 1 are shown the survival data for all parts of the experiment, at the beginning of the

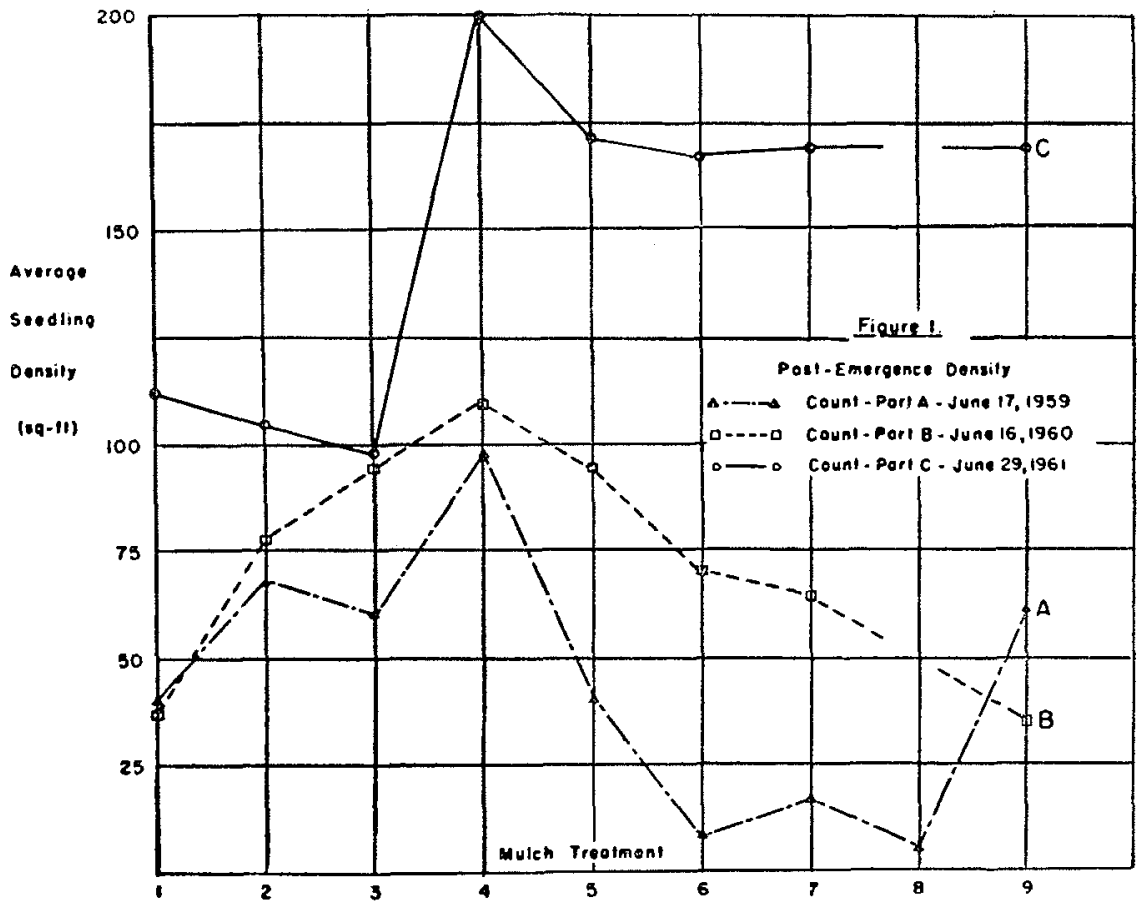

Figure 1. Average number of trees per square foot, for the highest count obtained in the spring of germination. Part A was sown in fall 1958, Part B in fall 1959, Part C in fall of 1960, and counts taken in following spring. Mulch treatments are described in the report. 
second growing season. Differences due to the effects of shading were not found to be significant.

It is apparent that the initial advantage of the sawdust mulch treatment continued. The residual stand, as shown in the columns of density per square foot was greatest in treatment No. 4, the sawdust mulch, in all three parts of the experiment. It was considerably above that of No. 9, the rye straw mulch. The differences are statistically significant at the 0.1 per cent level. Clifford ${ }^{(5)}$ also found a higher final stand with sawdust than with straw mulch.

TABLE 1

Survival and Percentage of Mortality from Highest Density at Beginning of Second Growing Season

\begin{tabular}{|c|c|c|c|c|c|c|c|}
\hline & & \multicolumn{2}{|c|}{ PART A } & \multicolumn{2}{|c|}{ PART B } & \multicolumn{2}{|c|}{ PART C } \\
\hline & & $\begin{array}{l}\text { Density } \\
\text { per sq ft. }\end{array}$ & $\begin{array}{c}\text { Mortality } \\
\%\end{array}$ & $\begin{array}{c}\text { Density } \\
\text { per sq ft. }\end{array}$ & $\begin{array}{c}\text { Mortality } \\
\%\end{array}$ & $\begin{array}{c}\text { Density } \\
\text { per sq.ft. }\end{array}$ & $\begin{array}{c}\text { Mortality } \\
\%\end{array}$ \\
\hline $1 S^{1}$ & \multirow[t]{2}{*}{ Silica \#4 } & 29.1 & 28.8 & 28.8 & 17.9 & 110.1 & 9.3 \\
\hline $1 N$ & & 34.7 & 17.6 & 43.9 & 2.2 & 95.1 & 11.0 \\
\hline $2 \mathrm{~S}$ & \multirow[t]{2}{*}{ Silica $\# 6$} & 41.6 & 30.2 & 78.2 & 23.6 & 94.5 & 8.9 \\
\hline $2 \mathrm{~N}$ & & 58.9 & 24.4 & 41.9 & 22.7 & 101.5 & 8.2 \\
\hline $3 S$ & \multirow[t]{2}{*}{ Silica \#8 } & 38.1 & 37.5 & 79.1 & 19.7 & 90.8 & 8.6 \\
\hline $3 N$ & & 32.6 & 46.4 & 59.8 & 33.1 & 91.6 & 8.6 \\
\hline $4 S$ & \multirow[t]{2}{*}{ Sawdust } & 98.3 & 15.7 & 106.1 & 7.5 & 193.0 & 18.7 \\
\hline $4 N$ & & 69.2 & 14.8 & 89.3 & 19.3 & 182.9 & 17.4 \\
\hline $5 \mathrm{~S}$ & \multirow[t]{2}{*}{ Vermiculite } & 31.5 & 11.0 & 65.4 & 12.1 & 177.4 & 8.5 \\
\hline $5 \mathrm{~N}$ & & 39.8 & 15.8 & 100.9 & 11.6 & 120.1 & 18.1 \\
\hline $6 S$ & \multirow[t]{2}{*}{ Sphagnum } & 5.5 & 40.2 & 47.4 & 35.0 & 113.0 & 25.3 \\
\hline $6 \mathrm{~N}$ & & 4.9 & 46.2 & 49.5 & 31.9 & 122.7 & 32.1 \\
\hline $7 S$ & Silica and & 12.8 & 48.2 & 51.6 & 19.0 & 135.9 & 18.1 \\
\hline $7 \mathrm{~N}$ & Sphagnum & 5.8 & 52.1 & 53.4 & 18.1 & 152.4 & 13.2 \\
\hline $8 S$ & \multirow[t]{2}{*}{ Fibre Mat } & 3.6 & 26.5 & & & & \\
\hline $8 \mathrm{~N}$ & & 2.8 & 42.8 & & & & \\
\hline $9 \mathrm{~S}$ & \multirow[t]{2}{*}{ Rye Straw } & 49.9 & 20.9 & 44.0 & 10.9 & 144.7 & 15.5 \\
\hline \multirow[t]{3}{*}{$9 N$} & & 50.6 & 15.7 & 18.1 & 16.6 & 142.6 & 15.8 \\
\hline & Treatment & \multirow{2}{*}{\multicolumn{2}{|c|}{$\begin{array}{c}\text { Sig. } 0.1 \% \\
\text { NS }\end{array}$}} & \multirow{2}{*}{\multicolumn{2}{|c|}{ Sig. $0.1 \%$}} & \multicolumn{2}{|c|}{ Sig. $0.1 \%$} \\
\hline & Shade & & & & & & JS \\
\hline
\end{tabular}

$S^{I}$ is shaded overwinter as 1-0 seedlings.

$\mathrm{N}$ is not-shaded overwinter as $1-0$ scedlings.

$1-9$ are treatments as described earlier.

Also in Table 1 are given the data, by treatments and by years, for the percentage of mortality from the point of highest stand count in the first growing season (usually obtained on the first count) to the surviving trees at the beginning of the second growing season. The plots containing the sawdust mulch suffered lower mortality than many of the other treatments, and were at about the same order of magnitude as the control (No.9). 
Hence, it may be concluded that the sawdust mulch produced considerable advantage in terms of germination and survival.

\section{Effects of Mulches on Prevention of Frost Heaving}

The data in Table 1 are of the number of living trees at the beginning of the second growing season. At the same time that this count was made, counts of the numbers of trees heaved were obtained. These were lying on the bed surface. These data are presented in Table 2.

TABLE 2

Numbers of Trees Heaved Per Square Foot and as a Percentage of Overwintering Stand

\begin{tabular}{|c|c|c|c|c|c|c|c|}
\hline & & \multicolumn{2}{|c|}{ PART A } & \multicolumn{2}{|c|}{ PART B } & \multicolumn{2}{|c|}{ PART C } \\
\hline & & $\begin{array}{c}\text { No. of } \\
\text { Trees } \\
\text { heaved } \\
\text { per sq. ft. }\end{array}$ & $\begin{array}{c}\text { Mortality } \\
\text { due to } \\
\text { heaving } \\
\%\end{array}$ & $\begin{array}{c}\text { No. of } \\
\text { Trees } \\
\text { heaved } \\
\text { per sq. ft. }\end{array}$ & $\begin{array}{c}\text { Mortality } \\
\text { due to } \\
\text { heaving } \\
\% \\
\end{array}$ & $\begin{array}{c}\text { No. of } \\
\text { Trees } \\
\text { heaved } \\
\text { per sq. } f t .\end{array}$ & $\begin{array}{c}\text { Martality } \\
\text { due to } \\
\text { heaving } \\
\%\end{array}$ \\
\hline $\begin{array}{l}1 \mathrm{~S}^{1} \\
1 \mathrm{~N}\end{array}$ & Silica \#4 & $\begin{array}{l}0.78 \\
0.78\end{array}$ & $\begin{array}{l}1.91 \\
1.85\end{array}$ & $\begin{array}{l}0.00 \\
0.02\end{array}$ & $\begin{array}{l}0.00 \\
0.04\end{array}$ & $\begin{array}{l}0.96 \\
1.12\end{array}$ & $\begin{array}{l}0.79 \\
1.05\end{array}$ \\
\hline $\begin{array}{l}2 \mathrm{~S} \\
2 \mathrm{~N}\end{array}$ & Silica $\# 6$ & $\begin{array}{l}0.52 \\
0.78\end{array}$ & $\begin{array}{l}0.87 \\
1.00\end{array}$ & $\begin{array}{l}0.06 \\
0.04\end{array}$ & $\begin{array}{l}0.06 \\
0.07\end{array}$ & $\begin{array}{l}1.00 \\
0.94\end{array}$ & $\begin{array}{l}0.96 \\
0.85\end{array}$ \\
\hline $\begin{array}{l}3 \mathrm{~S} \\
3 \mathrm{~N}\end{array}$ & Silica $\# 8$ & $\begin{array}{l}0.40 \\
0.42\end{array}$ & $\begin{array}{l}0.66 \\
0.69\end{array}$ & $\begin{array}{l}0.08 \\
0.00\end{array}$ & $\begin{array}{l}0.08 \\
0.00\end{array}$ & $\begin{array}{l}1.52 \\
2.00\end{array}$ & $\begin{array}{l}1.53 \\
1.98\end{array}$ \\
\hline $\begin{array}{l}4 \mathrm{~S} \\
4 \mathrm{~N}\end{array}$ & Sawdust & $\begin{array}{l}0.70 \\
1.56\end{array}$ & $\begin{array}{l}0.60 \\
1.92\end{array}$ & $\begin{array}{l}0.08 \\
0.08\end{array}$ & $\begin{array}{l}0.07 \\
0.07\end{array}$ & $\begin{array}{l}2.00 \\
2.20\end{array}$ & $\begin{array}{l}0.84 \\
0.99\end{array}$ \\
\hline $\begin{array}{l}5 \mathrm{~S} \\
5 \mathrm{~N}\end{array}$ & Vermiculite & $\begin{array}{l}0.74 \\
0.92\end{array}$ & $\begin{array}{l}2.09 \\
1.94\end{array}$ & $\begin{array}{l}0.10 \\
0.22\end{array}$ & $\begin{array}{l}1.34 \\
1.93\end{array}$ & $\begin{array}{l}1.10 \\
1.72\end{array}$ & $\begin{array}{l}0.57 \\
1.17\end{array}$ \\
\hline $\begin{array}{l}6 \mathrm{~S} \\
6 \mathrm{~N}\end{array}$ & Sphagnum & $\begin{array}{l}0.38 \\
0.26\end{array}$ & $\begin{array}{l}4.13 \\
2.86\end{array}$ & $\begin{array}{l}0.06 \\
0.06\end{array}$ & $\begin{array}{l}0.08 \\
0.08\end{array}$ & $\begin{array}{l}1.92 \\
2.34\end{array}$ & $\begin{array}{l}1.27 \\
1.29\end{array}$ \\
\hline $\begin{array}{l}7 \mathrm{~S} \\
7 \mathrm{~N}\end{array}$ & $\begin{array}{l}\text { Silica and } \\
\text { Sphagnum }\end{array}$ & $\begin{array}{l}0.24 \\
0.20\end{array}$ & $\begin{array}{l}0.97 \\
1.65\end{array}$ & $\begin{array}{l}0.04 \\
0.02\end{array}$ & $\begin{array}{l}0.06 \\
0.03\end{array}$ & $\begin{array}{l}1.12 \\
0.90\end{array}$ & $\begin{array}{l}0.68 \\
0.51\end{array}$ \\
\hline $\begin{array}{l}8 \mathrm{~S} \\
8 \mathrm{~N}\end{array}$ & Fibre Mat & $\begin{array}{l}0.86 \\
0.80\end{array}$ & $\begin{array}{l}17.65 \\
16.33\end{array}$ & & & & \\
\hline $\begin{array}{l}9 \mathrm{~S} \\
9 \mathrm{~N}\end{array}$ & Rye Straw & $\begin{array}{l}2.90 \\
5.24\end{array}$ & $\begin{array}{l}4.60 \\
8.73\end{array}$ & $\begin{array}{l}0.40 \\
0.56\end{array}$ & $\begin{array}{l}0.84 \\
2.58\end{array}$ & $\begin{array}{l}1.82 \\
1.10\end{array}$ & $\begin{array}{l}1.06 \\
0.65\end{array}$ \\
\hline & $\begin{array}{l}\text { Treatment } \\
\text { Shade }\end{array}$ & Sig. $0.1 \%$ & $1 \%$ & \multicolumn{2}{|c|}{ Sig. $0.1 \%$} & Sig. $0.1 \%$ & $\begin{array}{l}.1 \% \\
\mathrm{~S}\end{array}$ \\
\hline
\end{tabular}

${ }^{1}$ As defined for Table 1 .

The differences between treatments, in the numbers of trees heaved were significant in the first and third years (at $0.1 \%$ and $5.0 \%$ respectively) but not in the second year. Even though significant, there is still the question of whether the differences in heaving were related to the mulch treatment or to the stand density, which also differed significantly by treatments. This can be examined by a study of the data. As the effect of shading was not significant, the density of the five beds of the shaded phase and their heaving can be compared with the density of the five beds of the non-shaded 
phase and their respective heaving. It was found that there was no visible bias for dense beds to show less heaving, or the reverse. This implies that the heaving losses are more related to mulch treatment. The heaving losses, however, are not consistent over the three years; there is much variation between treatments. The mulch treatments of sawdust (No. 4), silica (No. 6) and sphagnum and silica (No. 7) all gave indications of lower losses from frost heaving than did the regular rye straw (No. 9).

In Table 2, the loss due to heaving is expressed as a percent of mortality from the highest stand density for each year. When this is compared with Table 1 it is apparent that the loss due to heaving is a minor part of the total loss, in the three years under examination.

It may be concluded that sawdust compared favourably with rye straw in reducing frost heaving, and that losses due to heaving were not as severe as generally believed.

\section{Effects of Mulches on Weeding}

The counts of the numbers of weeds were made during the first growing season when there was no distinction between the shaded and non-shaded phases of each mulch treatment. The highest weed count (at one time of counting) and the total weed count for the three or four counts in each year are given in Table 3 .

This shows that the rye straw mulch was the least favourable treatment in controlling weeds. On the other hand, the sawdust mulch gave very good control of weeds; it was the best treatment in two of the three years. The differences between treatments were highly significant in each year.

TABLE 3

Count of Weeds Per Square Foot

Showing Highest Number at One Count and

Total Number Removed in First Year

\begin{tabular}{lcccccc}
\hline & \multicolumn{2}{c}{ PART A } & \multicolumn{2}{c}{ PART B } & \multicolumn{2}{c}{ PART C } \\
\hline & $\begin{array}{c}\text { Highest } \\
\text { No. } \\
\text { per sq. ft. }\end{array}$ & $\begin{array}{c}\text { Total } \\
\text { No. }\end{array}$ & \multicolumn{2}{c}{$\begin{array}{c}\text { Highest } \\
\text { No. } \\
\text { per sq. }\end{array}$} & $\begin{array}{c}\text { Total } \\
\text { No. }\end{array}$ & \multicolumn{2}{c}{$\begin{array}{c}\text { Highest } \\
\text { No. } \\
\text { per sq ft. }\end{array}$} \\
\hline 1. Silica $\# 4$ & 20.1 & 53.0 & 12.7 & 20.7 & 69.5 & 118.1 \\
2. Silica $\# 6$ & 34.1 & 75.9 & 13.9 & 23.5 & 77.9 & 134.6 \\
3. Silica $\# 8$ & 19.0 & 40.9 & 13.2 & 18.0 & 79.0 & 136.8 \\
4. Sawdust & 24.2 & 62.2 & 6.6 & 8.4 & 25.0 & 49.4 \\
5. Vermiculite & 24.8 & 50.0 & 11.6 & 20.7 & 47.8 & 86.8 \\
6. Sphagnum & 4.8 & 11.9 & 23.1 & 30.0 & 38.3 & 72.0 \\
7. Silica and & & & & & & \\
$\quad$ Sphagnum & 16.3 & 30.9 & 24.8 & 35.3 & 65.1 & 114.5 \\
8. Fibre Mat & 14.4 & 30.9 & & & & \\
9. Rye Straw & 44.7 & 133.9 & 33.7 & 54.1 & 66.5 & 115.3 \\
$\quad$ Treatments & Sig. $0.1 \%$ & Sig $0.1 \%$ & \multicolumn{2}{c}{ Sig. $0.1 \%$} \\
\hline
\end{tabular}


Here again the question arises, was the density of the weed population related to the density of the tree population? This can be examined, as in the case of the heaving, by subdivision of treatments. The data were recorded for the shaded and non-shaded phases separately, although these distinctions did not apply at the time of counting. In all treatments and years there were 17 instances in which there were distinct differences in seedbed density. In 5 of these there were fewer weeds in denser beds but in the remaining 12 there were more weeds in denser beds. The inference is that more weeds could be expected in treatments which contained higher densities. However, by comparing Table 3 with Figure 1, it can be seen that this inference is not generally upheld. Hence, it is implied that weed population is more closely associated with mulch treatment than with seedbed density.

It is concluded that the sawdust mulch was more satisfactory in weed control than was the standard rye straw mulch.

\section{Effects of Mulches on Tree Size}

The nurseryman is also interested in the effects of the mulches on the size and balance of the seedlings. From seedling samples taken in the spring at the beginning of the third growing season, data were obtained on top-length (root collar to tip of terminal bud, in inches), root length (root collar to tip of longest root placed along a scale, in inches), stem diameter (about $1 / 2$ inch above root collar, in $\mathrm{cm}$.), oven-dry weight ( 24 hours at $105^{\circ} \mathrm{C}$. in grams), and top-root ratio (in terms of oven-dry weights). Ten trees were taken from each plot, a total of 900 from Part A, and 800 each from Parts B and C. Analyses of the data revealed manyi significant differences.

Only part of these data are presented, because of lack of space and general similarity in trends. The average oven-dry weights are presented in Figure 2. The differences between treatments were significant in all years. As can be seen both the sawdust mulch and the control (No. 9) produced comparatively light trees.

The top-length measurements are summarized in Figure 3. Again, it can be seen that both the sawdust mulch and the control treatments resulted in shorter trees.

Finally, the top-root ratios of all treatments are summarized in Figure 4. The sawdust mulch had developed seedlings with a relatively high ratio even in comparison with the rye straw mulch.

In summary then, it would appear that the sawdust mulch has produced small and poorly-balanced trees, and did not show as favourably here as in germination, in prevention of heaving, and in weed control.

However, bearing in mind that the sawdust mulch had the greatest bed densities, the question again arises as to how much of these differences in size are due to differences in seedbed density. The effects of the shading, which have application at this stage, were significant in terms of oven-dry weight and top-length. Therefore, we cannot compare as before.

It has been shown, however, that seedbed density affects size and weight. Muntz ${ }^{(15)}$ showed a decrease in green-weight and height with an increase in bed density over 30 seedlings per square foot. Reineke(16) also found a 


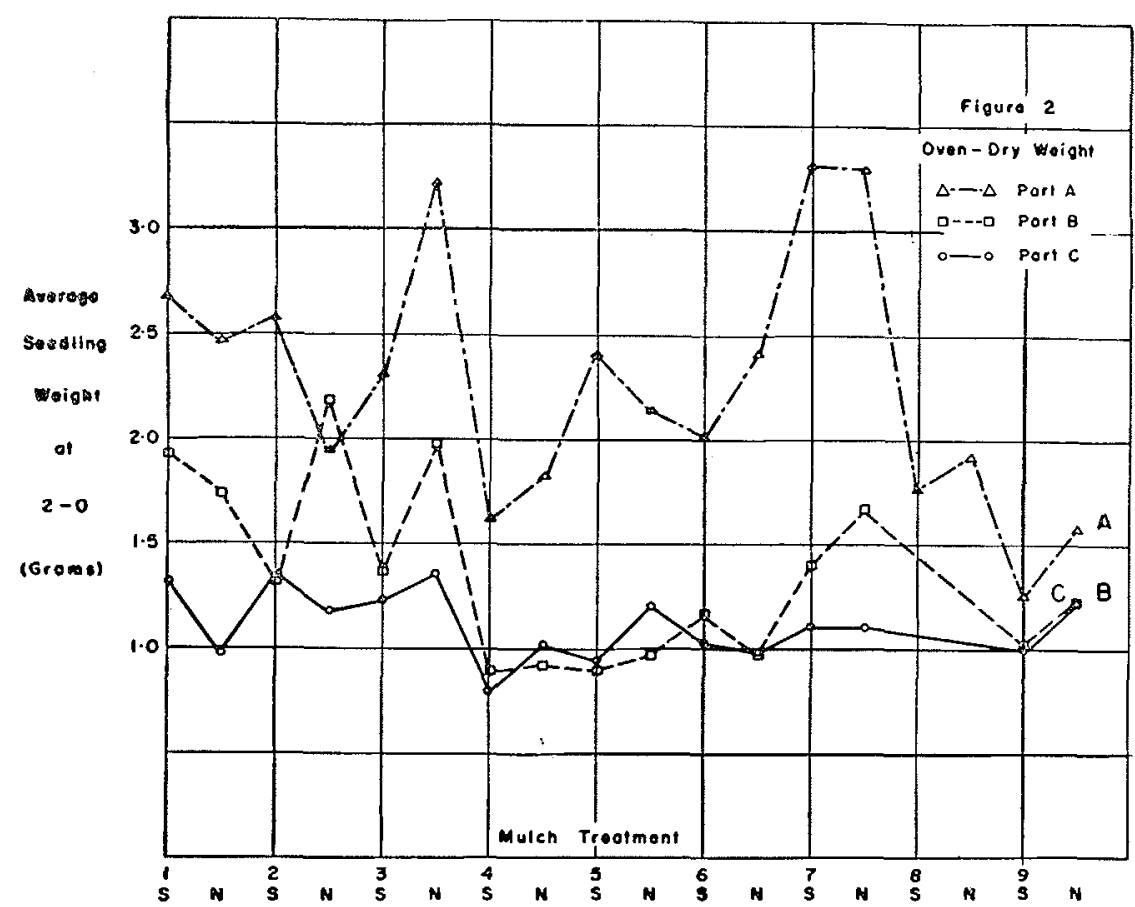

Figure 2. Average oven-dry weight of seedlings at 2-0 (grams). Dried 24 hours at $105^{\circ} \mathrm{C}$. Part A sown fall 1958, sampled spring 1961; Part B sown fall 1959, sampled spring 1962; Part C sown fall 1960, sampled spring 1963.

decrease in height, and in stem diameter with increasing density. Similarly, Switzer and Nelson ( 20$)$ found that plant size decreased with increasing bed density. Derr ${ }^{(6)}$ reported similar findings.

In this experiment, the data on oven-dry weight, (Figure 2) can be compared with those of seedbed density, (Table 1), and show a strong correlation; in the denser beds the trees are usually smaller.

Thus, while the effects of bed density and mulch treatment cannot be positively separated, it can be inferred that many of the size differences are due to bed density. Thus the small trees of the sawdust treatment are not indicative of stock which could be grown at a reduced density.

It can be concluded from this experiment that the sawdust mulch did not inhibit the growth of the stock significantly in comparison with the rye straw mulch.

\section{Effects of Shading}

In this experiment a test was made of the practice of leaving the lath shades on the beds during the winter between the first and second growing seasons, as compared with the usual practice of removing the shades in the early fall and replacing them in the late spring. 


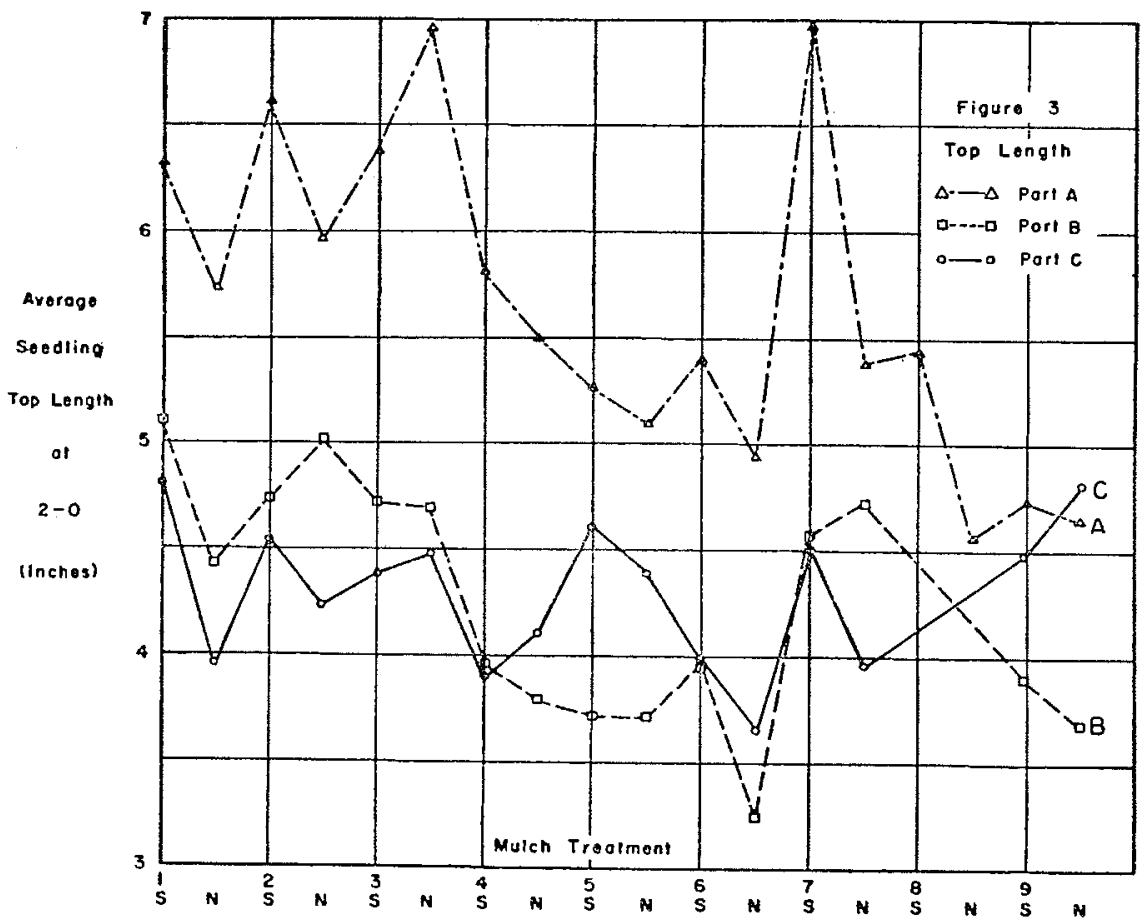

Frgure 3. Average top-length of seedlings at 2-0 (inches). Measured from root collar to tip of terminal bud. From the three parts of the experiment, samples taken spring 1961, spring 1962 and spring 1963.

Winter shading in this manner did not bave any significant effect on the rate of survival, or on the numbers of trees heaved. Similarly no effect was found on the numbers of weeds.

Shading did, however, have a significant effect on size of the trees, although this differed by treatments. In the two treatments under examination; namely, the sawdust mulch (No. 4), and the rye straw (No. 9), shading significantly reduced the oven-dry weight in Part A (see Figure 2) and followed a similar pattern in Parts B and C. Shading also produced taller trees in most comparisons, as shown in Figure 3.

Hence, it may be concluded that this form of shading offered no benefit over the regular procedure.

\section{Literature Cited}

${ }^{1}$ ALLISON, F. E. and M. S. ANDERSON, 1951. The use of sawdust for mulches and soil improvement. U.S. Dept. Agric. Circ. 891, 19 p.

${ }^{2}$ BALDWIN, H. I. 1959. Notes on nursery practice in Scotland. U.S. For. Service. Tree Planters' Notes 38:13-15. 


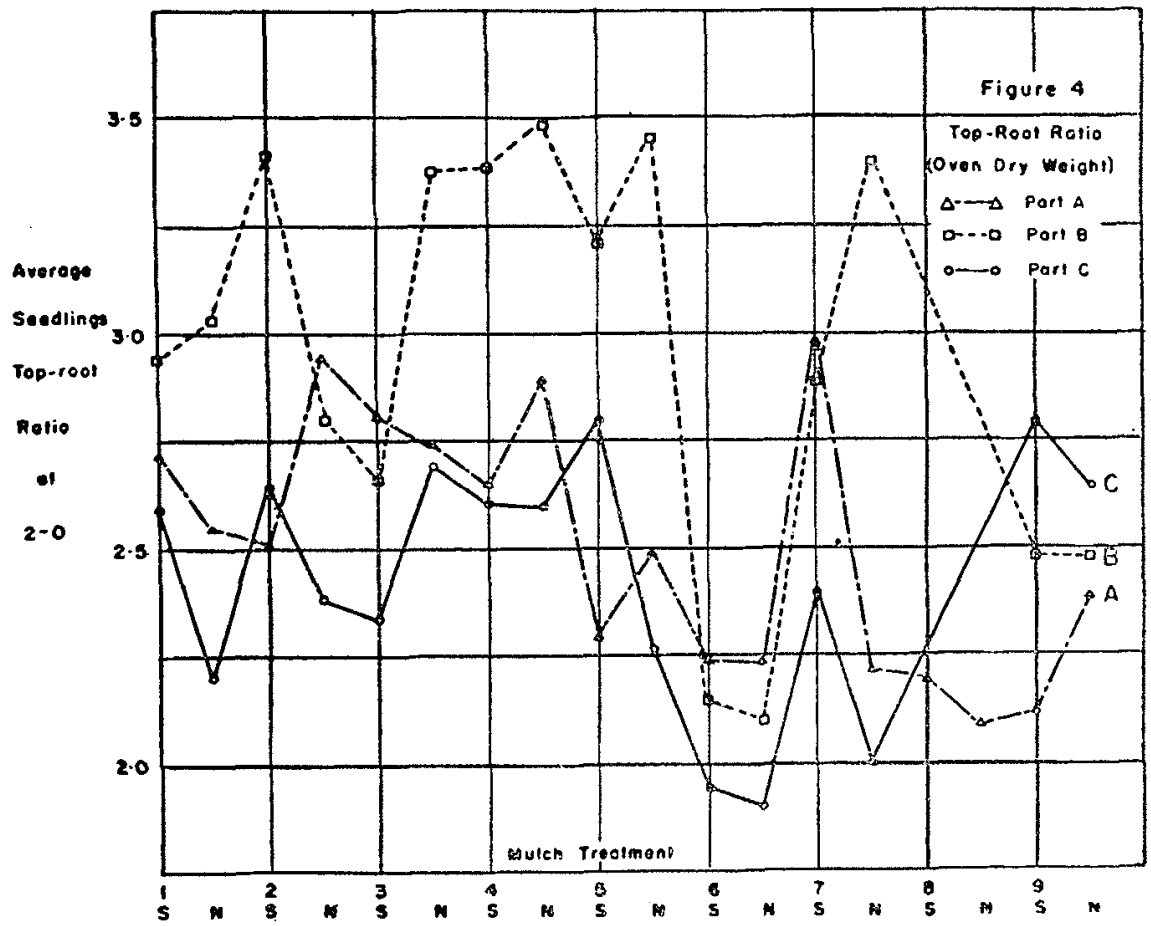

Fugure 4. Average top-root ratio at 2-0. Expressed in terms of oven-dry weights of tops and roots. From the three parts of the experiment, samples taken spring 1961, spring 1962 and spring 1963.

"BLOOMBFRG, W. J. 1963. Use of organic residue in forest nurseries. Bi-m. Prog. Rep. For. Ent. Path. Branch, Can. Dept. For. 19 (6):4.

${ }^{\star B O L L E N, ~ W . ~ B . ~ a n d ~ K . ~ L . ~ L U . ~ 1957 . ~ E f f e c t s ~ o f ~ D o u g l a s ~ f i r ~ s a w d u s t ~ m u l c h e s ~ a n d ~ i n c o r p o r a t i o n ~}$ on soil microbial activities and plant growth. Soil Sci. Soc. Proc. 21:35-41.

${ }^{\circ}$ CLIFFORD, E. D. 1955. The use of sawdust as a mulch on red, white and jack pine seedlings. U.S. For. Service. Tree Planters' Notes 21:24-25.

DERR, J. H. 1955. Seedbed density affects longleaf pine survival and growth. U.S. For. Service. Tree Planters' Notes 20:28-29.

'ENGSTROM, A. 1955. Polyethylene film for seedbed mulch. U.S. For. Service. Tree Planters" Notes $21: 26-27$.

FRESE, P. 1957. Handbook on mulches. Brooklyn Botanic Garden. Special printing of "Plants and Gardens" Vol. 13 (1) -80 p.

'KIRSCH, R. K. 1959. Effects of sawdust mulches. 1. Soil Properties. Oregon State College, Agric. Expt. Sta. Tech. Bull. 49. 15 p.

${ }^{10}$ KNIGHT, H. 1958. A test to determine acceptability of sawdust as a seedbed cover. U.S. For. Service. Tree Planters' Notes 31:10-14.

${ }^{n}$ KRAUSE, H. H. 1964. Sawdust as a source of organic matter for nursery soils. Conference on Artificial Regeneration in Ontario. Mimeograph report. 3-4.

${ }^{15 K R U S S M A N, ~ G . ~ 1954 . ~ D i e ~ B a u m s c h u l e . ~ P a u l ~ P a r c y . ~ B e r l i n . ~} 559$ p.

${ }^{20} L U N T, H$. A. 1953. Wood chips (and sawdust) as soil amendments. IN the we of wood chips in Agriculture. Northeastern Wood Utilization Council. Bull. 41:33-48. 
${ }^{14}$ MORRIS, C. L. 1960. Soil fumigation evaluation in white pine seedbeds and other nursery investigations. U.S. For. Service. Tree Planters' Notes 41:17-21.

${ }^{15}$ MUNTZ, H. H. 1944. Effects of compost and stand density upon longleaf and slash pine nursery stock. J. For. 42:114-118.

${ }^{10}$ REINEKE, L. H. 1942. Effect of stocking and seed on nursery development of eastern white pine seedlings. J. For. 40:577-578.

${ }^{17}$ ROBERTS, A. N. and W. M. MELLENTHIN. 1959. Effects of sawdust mulches. 11. Horticultural Crops. Oregon State College, Agric. Expt. Station, Tech. Bull. 50. 34 p.

${ }^{19}$ RUPF, H.; S. SCHONHAR; and M. ZEYHER. 1961. Der Forstpflanzgarten. BLV. Verlagsgesellschaft. Munich. 242 p.

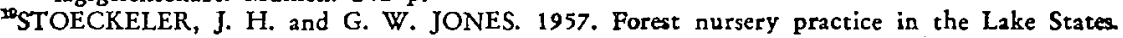
U.S. For. Service. Agric. Handbook 110. 124 p.

SWITZER, G. L. and L. B. NELSON. 1963. Effects of nursery fertility and density on seedling characteristics, yield and field performance of loblolly pine (Pinus taeda L.) Soil Sci. Soc. Proc. 27 (4):461-464.

mOUMEY, J. W. and C. F. KORSTIAN. 1942. Seeding and planting in the practice of forestry. 3rd Ed. John Wiley and Sons, New York. 520 p.

DEEBSTER, G. R. and R. M. ADAMSON. 1960. Effects of sawdust used as a mulch and as a soil amendment on soil temperature under irrigated and unirrigated conditions. Can. J. of Soil Sci. 40 (2):207-211.

WYCOFF, H. B. 1958. Experimental treatment of rawdust with anhydrous ammonia. U.S. For. Service. Tree Planters' Notes. 31:15-18. 